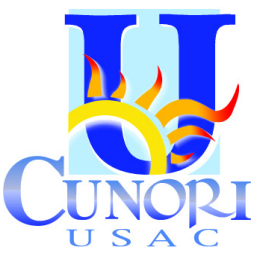

\title{
Revista Ciencia Multidisciplinaria CUNORI
} http://revistacunori.com

DOI: https://doi.org/10.36314/cunori.v2i1.63

ISSN: 2617- 474X (impresa) / 2617- 4758 (en línea)

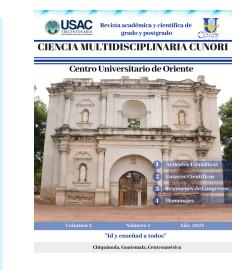

\section{P6 -La matanza de los patos: análisis de la memoria histórica en la reconstrucción de escenarios de masacres durante el conflicto armado interno en Guatemala}

\section{The killing of ducks: analysis of historical memory in the reconstruction of scenarios of massacres during the internal armed conflict in Guatemala}

\author{
Walter Paniagua*, María Teresa Mosquera \\ Escuela de Psicología, Universidad de San Carlos de Guatemala \\ ${ }^{2}$ Instituto de Estudios Interétnicos-USAC
}

$\begin{array}{ll} & \text { *Autor para correspondencia. } \\ \text { Resumen } & \text { Correo electrónico: paniagua.omar@usac.edu.gt }\end{array}$

$\mathrm{E}$ ntre las narraciones relacionadas al conflicto armado en la región tz'utujil sobresale un hecho denominado por los pobladores como la masacre de los patos. Esta ponencia articula tres fuentes de información que reconstruyen los hechos ocurridos el 7 de enero del año de 1981 en la finca San Isidro Chacayá, a decir, testimonios de familiares de víctimas, archivos fenecidos del Organismo Judicial y el caso ilustrativo 11 de la Comisión para el Esclarecimiento Histórico. La metodología empleada fue cualitativa y, a través de la investigación documental en los Archivos Regional de Tribunales de Quetzaltenango, se localizaron dos expedientes relacionados con la masacre. Se empleó el análisis crítico de fuentes como estrategia de interpretación para los expedientes judiciales para crear una narrativa que evidencie lo acontecido en la masacre, desde la lógica estatal a través del contenido de los archivos. Por otro lado, se realizaron cinco entrevistas con familiares de personas que murieron en este caso y se contrastó las narraciones con la información de archivo. Entre los hallazgos se evidencia la lógica empleada por el ejército para que el hecho no fuera reportado al Estado y la diseminación de cadáveres en lugares alejados de la jurisdicción de Santiago Atitlán.

Palabras clave: conflicto armado, masacres, Guatemala, testimonios, memoria histórica

Abstract

mong the narrations related to the armed conflict in the Tz'utujil region stands out a fact called by the settlers as the massacre Aof the ducks. This paper articulates three sources of information that reconstruct the events that took place on January 7 of the year of 1981 in the San Isidro Chacayá farm, to say, testimonies of relatives of victims, records of the Judicial Branch and illustrative case 11 of the Commission for the Historical Clarification. The methodology used was qualitative and, through documentary research in the Regional Archives of the Courts of Quetzaltenango, two files related to the massacre were located. The critical analysis of sources was used as an interpretation strategy for the judicial files to create a narrative that evidenced what happened in the massacre from the state logic through the content of the archives. On the other hand, there were five interviews with family members of people who died in this case and the narrations were contrasted with the file information. Among the findings is the logic used by the army so that the fact was not reported to the State and the dissemination of corpses in places far from the jurisdiction of Santiago Atitlán.

Keywords: armed conflict, massacres, Guatemala, testimonies, historical memory 


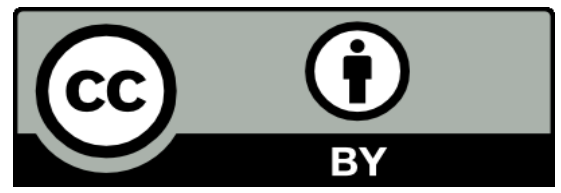

Este texto está protegido por una licencia CreativeCommons 4.0.

Usted es libre para compartir, copiar y redistribuir el material en cualquier medio o formato y adaptar el documento, remezclar, transformar y crear a partir del material para cualquier propósito, incluso comercialmente, siempre que cumpla la condición de atribución: usted debe reconocer el crédito de una obra de manera adecuada, proporcionar un enlace a la licencia, e indicar si se han realizado cambios. Puede hacerlo en cualquier forma razonable, pero no de forma tal que sugiera que tiene el apoyo del licenciante o lo recibe por el uso que hace. 